\title{
ANALISIS PENDAPATAN MASYARAKAT PELADANG DI KAWASAN PERBATASAN KABUPATEN KAPUAS HULU KALIMANTAN BARAT
}

\author{
(Income Analysis of Shifting Cultivator's Community in the Border Area of Kapuas Hulu \\ Regency West Kalimantan)
}

\author{
Yuli Widyawati, Emi Roslinda \\ Fakultas Kehutanan Universitas Tanjungpura Jalan Imam Bonjol Pontianak 78124 \\ E-mail: widyawatiyuli@gmail.com
}

\begin{abstract}
Shifting cultivation is an activity that cannot be separated from the community around the border of Kapuas Hulu Regency. Various factors influence the income of farmers. The aims of this research was to determine the income of rice farming on farmers and the relationship between income and the land area, the number of family members working in the fields and the number of working hours. Data was collected for two months from March 2016 until May 2016 at the study site through interviews with 97 families who were deliberately selected based on certain criteria. The method used in this study is a survey method with interviews using questionnaires. The collected data analyzed using associative descriptive analysis and multiple linear regression analysis. The results showed that the average net income obtained by farmers is $R p .2,379,917.76$ / respondent / planting season. If the labor wage costs are calculated, the farmer's income becomes Rp. -4,181,680,186/ respondent / planting season due to pest attacks. The results of the regression analysis show the relationship between farmer income and the variable land area, the number of family members working in the field and the number of working hours simultaneously have a significant effect on farmer income. Partially, only the variable number of working hours has a significant effect on farmer income in the border area of Kapuas Hulu Regency.

Keywords: income, land area, working hours, family members, cultivators
\end{abstract}

\section{PENDAHULUAN}

Kegiatan ladang berpindah masih banyak terdapat di Kalimantan Barat termasuk di daerah perbatasan Kapuas Hulu. Banyak masyarakatnya yang melakukan pertanian jenis ladang berpindah. Tercatat 247.306 orang penduduk Kapuas Hulu, dan 33,87 \% atau sekitar 83.765 orang masih mengusahakan ladang berpindah dengan luas tanam sebesar $9.233 \mathrm{Ha}$ dengan produksi 17.493 Ton serta produktivitasnya 1,5 Ton/Ha (BPS Kapuas Hulu, 2016).

Kegiatan berladang bertujuan untuk meningkatkan pendapatan agar keuntungan menjadi lebih tinggi.
Pendapatan tidak lepas dari faktor-faktor produksi yang dimiliki peladang untuk meningkatkan produksi hasil panennya. Dalam upaya peningkatan pendapatan petani padi, luas lahan sangat berpengaruh untuk meningkatkan pendapatan petani. Selain itu tenaga kerja yang terdiri dari jumlah anggota keluarga yang bekerja di ladang dan jumlah jam kerja juga berpengaruh terhadap tingkat pendapatan. Di sisi lain, sebagian besar kegiatan pertanian di Indonesia diusahakan oleh petani sebagai usahatani keluarga dengan kepemilikan lahan (tanah garapan) yang sempit yakni kurang dari 0,5 ha (Suratiyah,2011). Sempitnya lahan (tanah 
garapan) yang diusahakan oleh petani menyebabkan pendapatannya rendah, terutama pada usahatani lahan kering yaitu ladang.

Berladang merupakan kegiatan yang tidak bisa lepas dari masyarakat daerah perbatasan Kapuas Hulu. Selain untuk memenuhi kebutuhan pangan mereka, berladang juga merupakan tradisi yang secara turun-temurun telah dilaksanakan dan menjadi tradisi yang masih terus dipertahankan. Selain itu berladang juga merupakan sumber mata pencaharian masyarakat. Namun pendapatan dari hasil berladang di Kabupaten Kapuas Hulu tersebut belum diketahui secara rinci. Oleh karena itu penelitian ini bertujuan untuk menganalisis pendapatan dari hasil ladang dan hubungannya dengan faktor-faktor yang mempengaruhinya yaitu luas lahan yang digarap, jumlah anggota keluarga yang bekerja di ladang dan jumlah jam kerja.

\section{METODE PENELITIAN}

Penelitian ini dlaksanakan di kawasan perbatasan Kabupaten Kapuas Hulu meliputi empat dusun yaitu Dusun Bunut Lalau (Desa Janting Kecamatan Badau), Dusun Keluin (Desa Mensiau Kecamatan Batang Lupar), Dusun Sungai Telian (Desa Tinting Seligi Kecamatan Badau) dan Dusun Benua Tengah Hilir (Desa Benua Tengah Kecamatan Putusibau Utara) tanggal 15 Maret 2016 sampai tanggal 15 Mei 2016. Penentuan lokasi penelitian dilakukan secara purposive dengan pertimbangan adalah dusun-dusun yang berada di kawasan perbatasan dengan penduduk sebagian besar sebagai peladang. Metode yang digunakan dalam penelitian ini adalah metode survei dengan wawancara menggunakan kuisioner. Data yang terkumpul kemudian dianalisa menggunakan analisis deskriptif asosiatif, analisis regresi linier berganda dan uji asumsi klasik. Responden ditentukan dengan random sampling karena homogenitas masyarakat adalah suku Dayak dan bermata pencaharian sebagai peladang. Jumlah sampel setiap lokasi penelitian yaitu $97 \mathrm{KK}$ yang terdiri dari 32 KK di dusun Bunut Lalau, $10 \mathrm{KK}$ di dusun Keluin, $20 \mathrm{KK}$ di dusun Sungai Telian dan $35 \mathrm{KK}$ di dusun Benua Tengah Hilir.

Besarnya pendapatan diketahui dengan cara mengurangi total penerimaan yang diperoleh dengan total biaya yang telah digunakan dari kegiatan berladang yang dilakukan. Pendapatan dapat dirumuskan sebagai berikut (Soekartawi, 2002):

$$
\pi=\mathbf{T R}-\mathbf{T C}
$$

Dimana:

$$
\begin{array}{ll}
\pi & =\text { Pendapatan hasil ladang }(\mathrm{Rp}) \\
\mathrm{TR} & =\text { Total penerimaan }(\mathrm{Rp}) \\
\mathrm{TC} & =\text { Total biaya }(\mathrm{Rp})
\end{array}
$$

Total biaya dapat dihitung menggunakan rumus sebagai berikut (Soekartawi, 2002):

$\mathbf{T C}=\mathbf{F C}+\mathrm{VC}$

Dimana:

$\mathrm{TC}=$ Total biaya $(\mathrm{Rp})$

$\mathrm{FC}=$ Biaya tetap $(\mathrm{Rp})$

$\mathrm{VC}=$ Biaya tidak tetap (Rp).

Penerimaan dapat dihitung dengan menggunakan rumus sebagai berikut (Soekartawi, 2002):

$$
\mathbf{T R}=\mathbf{P} \cdot \mathbf{Q}
$$

Dimana:

$\mathrm{TR}=$ Total penerimaan 
$\mathrm{Q}=$ Jumlah gabah yang dihasilkan $(\mathrm{Kg})$

$\mathrm{P}=$ Harga gabah $(\mathrm{Rp})$.

Untuk mencari hubungan (kolerasi) yang menghubungkan antara variabel pendapatan dan variabel-variabel yang diduga mempengaruhinya menggunakan persamaan regresi linier berganda sebagai berikut (Prajitno, 1981):

$\mathbf{Y}_{\mathbf{j}}=\boldsymbol{\beta}_{\mathbf{0}}+\boldsymbol{\beta}_{1} \mathbf{X}_{1 \mathbf{j}}+\boldsymbol{\beta}_{2} \mathbf{X}_{2 j}+\cdots+\boldsymbol{\beta}_{\mathrm{p}} \mathbf{X}_{\mathrm{pj}}+\mathbf{e}_{\mathbf{j}}$

Dimana :

$\hat{Y}=$ Pendapatan responden dari hasil ladang per tahun (Rp/tahun)

$\mathrm{X}_{1}=$ luas lahan yang digarap (Ha/tahun)

$\mathrm{X}_{2}=$ jumlah anggota keluarga yang bekerja di ladang per tahun (jiwa/tahun) $\mathrm{X}_{3}=$ Jumlah jam kerja per tahun (jam/tahun)

$\mathrm{e}_{\mathrm{j}}=$ error

$\beta_{0,}, \beta_{1}, \beta_{2}, \beta_{3}, \beta_{\mathrm{p}}=$ koefisien masingmasing variabel bebas
HASIL DAN PEMBAHASAN Pendapatan Peladang

Pendapatan berladang adalah selisih antara penerimaan dari hasil berladang dengan biaya total yang dikeluarkan oleh peladang per musim tanam. Berikut ini adalah uraian tentang jumlah biaya produksi, penerimaan, dan pendapatan peladang di lokasi penelitian yaitu kawasan perbatasan Kabupaten Kapuas Hulu dalam kegiatan berladang yang telah dilakukan.

\section{Biaya Produksi}

Biaya dalam penelitian ini terdiri dari biaya benih, pupuk, herbisida, insektisida, angkutan, dan chainsaw. Berikut ini merupakan komponen biaya yang dikeluarkan peladang dalam satu tahun produksi.

Tabel 1. Komponen Biaya yang Dikeluarkan Peladang dalam Satu Tahun Produksi (Components of Costs used by Cultivators in One Year of Production)

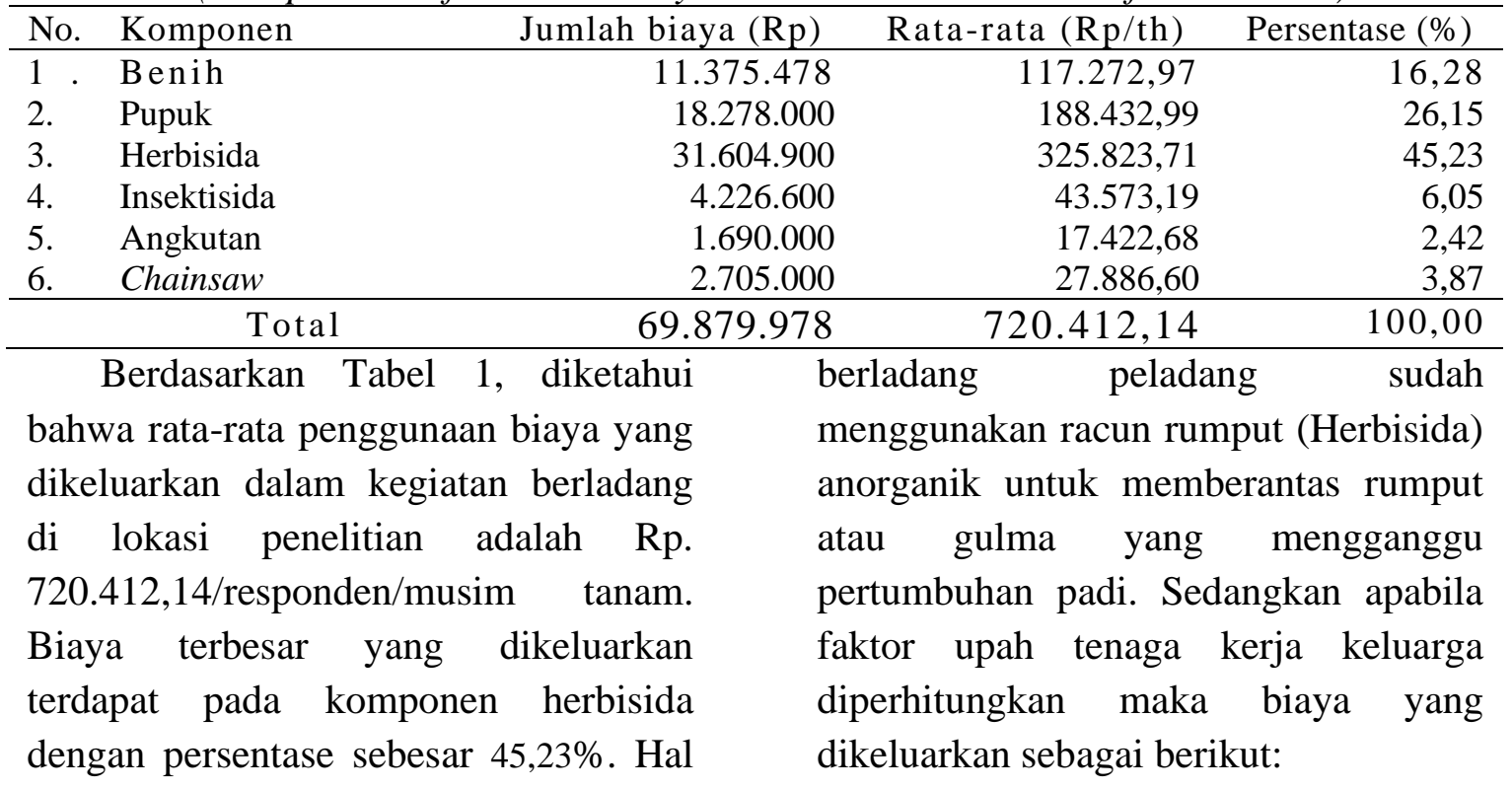


Tabel 2. Komponen Biaya dan Upah yang Dikeluarkan Peladang dalam Satu Tahun Produksi (Components of Costs and Wages used by Cultivators in One Year of Production)

\begin{tabular}{|c|c|c|c|c|}
\hline No & Komponen & Jumlah biaya (Rp) & Rata-rata $(\mathrm{Rp} / \mathrm{th})$ & Persentase $(\%)$ \\
\hline 1 & Benih & 11.375 .478 & $117.272,97$ & 1,61 \\
\hline 2. & Pupuk & 18.278 .000 & $188.432,99$ & 2,59 \\
\hline 3. & Herbisida & 31.604 .900 & $325.823,71$ & 4,48 \\
\hline 4. & Insektisida & 4.226 .600 & $43.573,19$ & 0,60 \\
\hline 5. & Angkutan & 1.690 .000 & $17.422,68$ & 0,24 \\
\hline 6. & Chainsaw & 2.705 .000 & $27.886,60$ & 0,38 \\
\hline 7. & Upah & 636.475 .000 & $6.561 .597,94$ & 90,10 \\
\hline & Total & 706.354 .978 & 7.282 .010 & 100,00 \\
\hline
\end{tabular}

di lokasi penelitian adalah Rp. 7.282.010/responden/musim tanam. Biaya terbesar yang dikeluarkan terdapat pada komponen upah dengan persentase sebesar 90,10\%. Hal ini dikarenakan dalam kegiatan berladang mulai dari menebas, menebang, membakar, menanam, merumput, sampai panen memerlukan banyak

Tabel 3. Rata-rata Pendapatan Peladang Per Responden Pada Musim Tanam 2015-2016 (Average Cultivator's Income Per Respondent in 2015-2016 Planting Season)

\begin{tabular}{lll}
\hline No. & Komponen & Jumlah \\
\hline 1. & Produksi (Kg/responden) & 516,72 \\
2. & Penerimaan (Rp) & $3.100 .329,90$ \\
3. & Biaya (Rp) & $720.412,14$ \\
\hline & Pendapatan (Rp) & $2.379 .917,76$
\end{tabular}

Berdasarkan Tabel 3 diketahui bahwa penerimaan dari hasil berladang yaitu sebesar Rp. 3.100.329,90 yang merupakan perkalian antara rata-rata produksi dan harga jual gabah. Dalam penelitian ini diasumsikan bahwa seluruh hasil padi ladang dijual meskipun kenyataannya peladang tidak pernah menjual padi ladangnya namun hanya untuk konsumsi sehari-hari. Ratarata produksi yaitu $516,72 \mathrm{~kg}$ per responden dan rata-rata harga gabah $\mathrm{Rp}$.

\section{Penerimaan dan Pendapatan Hasil} Ladang

Berdasarkan hasil penelitian, ratarata penerimaan dan pendapatan yang diterima oleh setiap peladang responden dalam kegiatan berladang yang telah dilakukan pada tahun tanam 2015-2016 sebagai berikut :
$6000,-/ \mathrm{kg}$ dengan perhitungan sebagai berikut:

$$
\begin{aligned}
& \mathrm{TR}=\mathrm{P} \times \mathrm{Q} \\
& \mathrm{TR}=6000 \times 516,72 \\
& \mathrm{TR}=3.100 .329,90
\end{aligned}
$$

Pendapatan berladang adalah selisih antara penerimaan dari hasil berladang dengan biaya total yang dikeluarkan oleh peladang per tahun. Berdasarkan perhitungan yang telah dilakukan maka pendapatan yang diperoleh peladang adalah sebesar Rp. 
2.379.917,76/responden/musim tanam dengan perhitungan sebagai berikut:

$$
\begin{aligned}
& \pi=\mathrm{TR}-\mathrm{TC} \\
& \pi=3.100 .329,90-720.412,14 \\
& \pi=2.379 .917,76
\end{aligned}
$$

Analisis pendapatan dalam penelitian ini digunakan untuk mengetahui besarnya pendapatan yang diperoleh peladang responden di lokasi penelitian. Produktivitas padi ladang di lokasi penelitian yaitu sebesar $431,8 \mathrm{~kg} / \mathrm{ha}$. Produktivitas padi ladang pada musim tanam 2015-2016 sangat rendah. Jumlah tersebut jauh lebih kecil dari menurut Badan Pusat Statistik Kapuas Hulu Dalam Angka Tahun 2011 yang menyatakan bahwa produktivitas padi ladang di Kapuas Hulu yaitu 1,5 Ton/Ha. Penelitian (Rosana, 2012) menjelaskan bahwa produktivitas padi ladang sangat rendah rata-rata hanya sekitar 1 - 1,5 ton gabah perhektar permusim tanam. Hal ini disebabkan oleh serangan hama Empangau (Leptocorisa acuta) pada saat padi mengeluarkan bulirnya yaitu pada bulan

Tabel 4. Rata-rata Pendapatan Peladang dangan UpahPer Responden Pada Musim Tanam 2015-2016 (Average of Cultivator's Income with Wages Per Respondent in 2015-2016 Planting Season)

\begin{tabular}{llc}
\hline No. & Komponen & Jumlah \\
\hline 1. & Produksi $(\mathrm{Kg} /$ responden) & 516,72 \\
2. & Penerimaan (Rp) & $3.100 .329,90$ \\
3. & Biaya (Rp) & $720.412,14$ \\
4. & Upah tenaga kerja dalam keluarga (Rp) & $6.561 .597,94$ \\
5. & Pendapatan (Rp) & $-4.181 .680,186$ \\
\hline \multicolumn{2}{l}{ Berdasarkan Tabel 4 pendapatan } & $\pi=3.100 .329,90-7.282 .010,08$ \\
peladang menjadi Rp. $-4.181 .680,186$ & $\pi=-4.181 .680,186$ \\
/responden/musim tanam yang & Pendapatan bernilai
\end{tabular}
merupakan hasil pengurangan dari total penerimaan dan total biaya disertai upah dengan perhitungan sebagai berikut:

$$
\pi=\mathrm{TR}-\mathrm{TC}
$$

Januari sampai Februari 2016 sehingga bulir-bulir padi tersebut tidak berisi dan kering. Hama ini umumnya menyerang tanaman padi pada fase pemasakan dengan cara menghisap cairan bulir padi yang sedang mengisi sehingga menyebabkan bulir padi menjadi hampa atau pengisiannya tidak sempurna (Feriadi, 2015). Serangan hama Empangau ini sudah pernah terjadi sebelumnya namun tahun 2016 merupakan serangan terparah sehingga hasil panen sangat jauh berkurang. Selain hama empangau, hama lain seperti babi, monyet dan burung juga menurunkan produktivitas hasil ladang. Penurunan hasil panen bisa terjadi dalam kondisi-kondisi tertentu, terutama jika kesuburan tanah amat rendah akibat kekurangan materi organik tanah (Suprapto, 2010).

Apabila upah tenaga kerja diperhitungkan, maka rata-rata pendapatan peladang dapat dilihat pada tabel 4 dibawah ini.

Pendapatan bernilai negatif dikarenakan oleh tenaga kerja dan jam kerja yang digunakan cukup banyak untuk berladang mulai dari 
membersihkan lahan hingga panen sehingga apabila dihitung dengan upah maka biaya yang dikeluarkan menjadi sangat besar walaupun pada kenyataannya mereka tidak pernah membayar tenaga kerja dengan uang.

Padi ladang bukan merupakan sumber mata pencaharian utama responden. Ladang diusahakan untuk memenuhi kebutuhan pangan seharihari mereka dan merupakan tradisi yang telah dilakukan sejak zaman nenek moyang. Hal ini sesuai dengan yang diungkapkan Indraningsih et al. (2003) yang menyatakan bahwa penanaman padi ladang oleh petani setempat yang masih bersifat subsisten, belum berorientasi komersial. Keterbatasan

\begin{tabular}{|l|l|l|l|l|}
\hline \multicolumn{1}{|c|}{ Variabel } & \multicolumn{1}{|c|}{$\begin{array}{c}\text { Koefisien } \\
\text { regresi }\end{array}$} & $\begin{array}{c}\text { Std. } \\
\text { Error }\end{array}$ & \multicolumn{1}{c|}{$\mathrm{T}_{\text {hitung }}$} & \multicolumn{1}{|c|}{ Signifikansi } \\
\hline Konstanta & 6,805 & 1,044 & 6,521 & Nyata \\
Luas lahan yang digarap & $-0,214$ & 0,319 & $-0,670$ & Tidak Nyata \\
Jumlah anggota keluarga & 0,187 & 0,347 & 0,540 & Tidak Nyata \\
yang bekerja di ladang & & & & \\
Jumlah jam kerja & 1,055 & 0,198 & 5,325 & Nyata \\
\hline $\mathrm{R}^{2}=0,275$ & & & \\
$\mathrm{~F}$ hitung $=11,784$ & & & \\
$\mathrm{~F}$ tabel 95\% $=2,702509$ & & & \\
$\mathrm{~F}$ tabel 99\% $=3,999442$ \\
$\mathrm{~T}$ tabel 95\% $=1,985802$ \\
$\mathrm{~T}$ tabel 99\% $=2,629732$ \\
Taraf kepercayaan 95\% dan 99\%
\end{tabular}

faktor produksi usahatani (lahan, tenaga kerja dan modal) serta pengetahuan petani di daerah lahan kering menyebabkan pola tanam yang selama ini diusahakan masih bersifat subsistem.

Hubungan Antara Pendapatan dan Faktor Luas Lahan yang Digarap, Jumlah Anggota Keluarga yang Bekerja di Ladang dan Jumlah Jam Kerja

Persamaan regresi linier berganda digunakan untuk melihat hubungan antara variabel pendapatan dan variabelvariabel yang mempengaruhinya yaitu luas lahan yang digarap, jumlah anggota kelarga yang bekerja di ladang dan jumlah jam kerja.

Tabel 5. Hasil Analisis Regresi Variabel (Results of Variable Regression Analysis)

Berdasarkan hasil analisis regresi pada Tabel 5diatas, diperoleh persamaan regresi sebagai berikut : $Y=6,805-0,214 X_{1}+0,187 X_{2}+1,055 X_{3}+e$

Hasil analisis data pada Tabel 5 . diketahui bahwa terdapat variabel yang berpengaruh secara signifikan dan ada yang tidak signifikan terhadap pendapatan peladang di kawasan perbatasan Kabupaten Kapuas Hulu. Penjelasaan mengenai hubungan antara variabel pendapatan dan variabelvariabel yang mempengaruhinya yaitu luas lahan yang digarap, jumlah anggota kelarga yang bekerja di ladang dan 
jumlah jam kerja adalah sebagai berikut:

\section{Hubungan Antara Luas Lahan yang Digarap Terhadap Pendapatan Peladang}

Berdasarkan hasil pengolahan data yang telah dilakukan, diketahui bahwaKoefisien luas lahan yang digarap sebesar -0,214, yang berarti setiap penambahan luas lahan yang digarap sebesar 1 ha, maka akan terjadi penurunan pendapatan peladang sebesar Rp. 0,214, dengan asumsi jumlah anggota keluarga yang bekerja di ladang dan jumlah jam kerja diasumsikan tetap. Hal ini menunjukkan bahwa luas lahan yang digarap mempunyai pengaruh negatif dan tidak signifikan terhadap pendapatan peladang di kawasan perbatasan Kabupaten Kapuas Hulu. Hasil ini diperoleh dari penelitian luas lahan yang dimiliki responden yaitu rata-rata $1,197 \mathrm{Ha}$ dari total lahan ratarata $13,457 \mathrm{Ha}$ atau sekitar $8,89 \%$ dari total lahan yang mereka miliki.

Luas lahan merupakan salah satu faktor penentu pengambilan keputusan dalam mengelola lahan. Penggunaan benih, pupuk, pestisida dan sebagainya akan dipengaruhi oleh luas lahan yang dimiliki yang akan berpengaruh terhadap biaya yang akan dikeluarkan selama musim tanam tersebut. Semakin luas lahan yang digunakan maka biaya yang digunakan semakin besar. Namun hasil panen yang sangat sedikit menyebabkan variabel luas lahan menjadi negatif. Hal ini disebabkan oleh yang disebabkan oleh serangan hama Empangau yang menyebabkan berkurangnya hasil panen padi secara signifikan. Sedangkan Pemambahan luas lahan yang digarap menyebabkan penghasilan menjadi rendah. Umumnya apabila seseorang memiliki luas lahan yang digarap besar maka akan memiliki pendapatan yang besar pula. Hal ini juga diungkapkan oleh Damanik (2014) yang menyatakan semakin luas lahan yang ditanami, maka semakin besar jumlah produksi yang dihasilkan lahan tersebut. Namun demikian ada juga seseorang yang memiliki lahan yang luas tapi berpenghasilan rendah dan sebaliknya. Tidak menutup kemungkinan bahwa seseorang yang memiliki luas lahan yang sempit akan berpenghasilan tinggi. Hal ini tergantung pada bagaimana orang tersebut mengelola lahan yang dimilikinya. Pada luasan lahan yang sempit, upaya pengusahaan terhadap penggunaan faktor produksi semakin baik, penggunaan tenaga kerja tercukupi dan tersedianya modal juga tidak terlalu besar, sehingga usaha pertanian seperti ini sering lebih efisien (Soekartawi, 1993).

Hasil penelitian ini sejalan dengan penelitian Anggraini (2012) yang menyatakan faktor luas lahan merupakan faktor yang tidak berpengaruh terhadap pendapatan petani dan arah hubungan kedua variabel tersebut bersifat negatif. Hal yang sama juga diungkapkan Apriadi (2015) yang menyatakan bahwa luas lahan tidak berpengaruh signifikan terhadap pendapatan petani padi di Kecamatan Banyuwangi pada taraf kepercayaan sebesar $95 \%$. 


\section{Hubungan Antara Jumlah Anggota Keluarga yang Bekerja di Ladang Terhadap Pendapatan Peladang}

Penggunaan tenaga kerja yang efektif dapat mendorong keberhasilan dalam berusahatani, disamping memiliki keterampilan serta pengalaman yang memadai merupakan faktor yang sangat penting dalam keberhasilan (Susianti dan Rauf, 2013). Berdasarkan data pada Tabel 12, diketahui bahwa koefisien $\mathrm{X}_{2}$ didapat angka 0,187 yang berarti setiap penambahan jumlah anggota keluarga yang bekerja di ladang sebanyak $1 \%$, maka akan terjadi kenaikan pendapatan peladang sebesar Rp. 0,187 dengan asumsi luas lahan yang digarap dan jumlah jam kerja diasumsikan tetap. Hal ini menunjukkan bahwa pengaruh jumlah anggota keluarga yang bekerja di ladang berpengaruh positif dantidak signifikan terhadap pendapatan peladang di kawasan perbatasan Kabupaten Kapuas Hulu. Hal ini dapat dilihat dari nilai koefisien regresi yang bernilai positif sedangkan nilai signifikan yang diperoleh dari $t_{\text {hitung }}<$ $t_{\text {tabel. }}$ Nilai $t_{\text {hitung }}$ pada variabel jumlah anggota keluarga yang bekerja di ladang adalah 0,098. Nilai tersebut lebih kecil dari nilai $t_{\text {tabel }}$ sebesar 1,985802. Artinya bahwa jumlah anggota keluarga yang bekerja di ladang berpengaruh tetapi tidak signifikan terhadap pendapatan peladang. Hal ini disebabkan karena sistem kerja pada lokasi penelitian adalah sistem "balas hari" yaitu sistem gotong-royong secara bergantian antar peladang. Selain itu tergantung pada kecepatan peladang tersebut dalam mengerjakan pekerjaannya. Misalnya peladang yang usianya sudah senja maka kecepatannya dalam bekerja akan berkurang sehingga memerlukan waktu yang cukup lama untuk menyelesaikannya.

Jumlah anggota keluarga yang bekerja di ladangyang dimaksud dalam penelitian ini adalah jumlah anggota keluarga yang ikut mengelola ladang secara aktif mulai dari penebasan hingga panen dengan satun hitung orang dalam sekali panen. Menurut Mubyarto (1985) menyatakan bahwa dalam usahatani, sebagian besar tenaga kerja berasal dari keluarga sendiri yang terdiri atas ayah, ibu, dan anak. Ketika jumlah tenaga kerja yang digunakan sedikit maka produksi ladangakan sedikit sehingga akan berpengaruh pada pendapatan, dan sebaliknya.

Penggunaan tenaga kerja di lokasi penelitian berasal dari keluarga maupun non keluarga. Tenaga kerja non keluarga adalah tetangga sesama peladang yaitu dengan sistem balas hari. Mereka membantu mengerjakan ladang seseorang kemudian orang tersebut secara bergantian membantu di ladang mereka. Hal ini merupakan tradisi yang turun menurun mereka lakukan sejak zaman nenek moyang. Hampir semua kegiatan mereka lakukan dengan balas hari dan gotong-royong mulai dari menebas, menebang, membakar, menanam benih, merumput hingga panen.

Hasil penelitian ini sama dengan kesimpulan penelitian oleh Damanik (2014) yang memberi kesimpulan 
bahwa jumlah tenaga kerja berpengaruh tetapi tidak signifikan terhadap pendapatan petani padidi Kecamatan Masaran, Kabupaten Sragen. Hal ini disebabkan karena sistem kerja pada daerah penelitian adalah sistem borongan.

\section{Hubungan Antara Jumlah Jam Kerja Terhadap Pendapatan Peladang}

Jumlah jam kerja adalah alokasi waktu kerja responden dan keluarganya yang digunakan untuk kegiatan berladang. Berdasarkan hasil regresi dapat disimpulkan bahwa jumlah jam kerja berpengaruh signifikan dan positif terhadap pendapatan peladang di kawasan perbatasan Kabupaten Kapuas Hulu. Jika diasumsikan semua variabel tetap maka setiap kenaikan 1 jumlah jam kerja akan meningkatkan 1,055 pendapatan peladang di lokasi penelitian. Jadi seorang peladang dengan jumlah jam kerja yang banyak maka akan meningkatkan pendapatan mereka. Secara teoritis, tiap anggota rumah tangga akan mencurahkan waktunya pada pekerjaan tertentu bila pendapatan yang dihasilkan dari pekerjaan tersebut cukup menarik baginya. Pada dasarnya pendapatan seseorang tergantung pada jam kerja yang dicurahkan dan tingkat pendapatan per jam kerja yang diterima.

Jumlah jam kerja menentukan besar kecilnya pendapatan dari berladang. Apabila hasil panen yang diperoleh banyak maka akan membutuhkan waktu yang banyak pula untuk memanennya.

\section{Kesimpulan}

Berdasarkan uraian hasil penelitian yang telah dilakukan, maka dapat disimpulkan hasil penelitian sebagai berikut:

1. Pendapatan bersih rata-rata yang diperoleh peladang dari hasil berladang sebesar Rp 2.379.917,76/responden/musim tanam. Apabila biaya upah tenaga kerja diperhitungkan maka pendapatan peladang menjadi Rp.4.181.680,186 /responden/musim tanam.

2. Hubungan antara pendapatan peladang dengan variabel luas lahan yang digarap, jumlah anggota keluarga yang bekerja di ladang dan jumlah jam kerjasecara simultan berpengaruh nyata terhadap pendapatan peladang.

3. Secara parsial, hanya variabel jumlah jam kerja yang berpengaruh nyata terhadap pendapatan peladang di kawasan perbatasan Kabupaten Kapuas Hulu.

4. Nilai koefisien determinasi $\left(\mathrm{R}^{2}\right)$ sebesar 0,275 menunjukkan bahwa variasi faktor pendapatan peladang dapat diterangkan oleh semua variabel bebas sebesar 27,5 \% sedangkan 72,5\% disebabkan oleh faktor lain yang tidak dimasukan dalam model.

\section{Saran}

Pembinaan dan pelatihan dari instansi terkait terhadap peladang mengenai pola tanam yang tepat agar lebih produktif dan menguntungkan serta penggantian penggunaan pupuk 
anorganik dengan memanfaatkan kotoran ternak menjadi pupuk organik sehingga dapat mengurangi biaya produksi ladang.

\section{DAFTAR PUSTAKA}

Anggraini S. 2012. Analisis FaktorFaktor yang Mempengaruhi Pendapatan Petani Padi ( Studi Kasus Desa Bentakan, Kecamatan Baki, Kabupaten Sukoharjo, Jawa Tengah,Tahun 2011) [Naskah Publikasi Ilmiah]. Surakarta: Fakultas Ekonomi Jurusan Ilmu Ekonomi Studi Pembangunan, Universitas Muhammadiyah Surakarta.

Apriadi P. 2015. Analisis Pengaruh Modal, Jumlah Hari Kerja, Luas Lahan,

Pelatihan Dan Teknologi Terhadap Pendapatan Petani Padi Di Kecamatan Gambiran Kabupaten Banyuwangi. Artikel Ilmiah Mahasiswa 2015

[BPS] Badan Pusat Statistik Kabupaten Kapuas Hulu. 2016. Kabupaten Kapuas Hulu Dalam Angka 2016. Badan Pusat Statistik Kabupaten Kapuas Hulu.

Damanik JA. 2014. Analisis FaktorFaktor yang Mempengaruhi Pendapatan Petani Padi di Kecamatan Masaran, Kabupaten Sragen. Economics Depelopment Analysis Journal (1): 212-224

Feriadi, 2015. Pengendalian Hama Walang Sangit (Leptcorisa oratorius) Pada Tanaman Padi Sawah.

http://bbpadi.litbang.deptan.go.id/ index.php/in/hama-padi/ 206-hama-walang-sangit-leptcorisaoratorius-.html [20 Sep 2016]
Indraningsih KS, Sejati WK dan Wahyuni S. 2003. Analisis Preferensi Petani Terhadap Karakteristik Teknologi Padi Ladang (Kasus Di Kabupaten Lampung Tengah dan Lampung Selatan, Propinsi Lampung). Bogor: Pusat Penelitian Dan Pengembangan Sosial Ekonomi Pertanian.

Mubyarto, 1985. Pengantar Ilmu Pertanian. Jakarta : LP3ES.

Prajitno D. 1985.Analisa Regresi dan Korelasi untuk Penelitian Pertanian. Yogyakarta: Liberty.

Rosana L. 2012. Analisis Harga Pokok Padi Sawah dan Padi Ladang di Kecamatan Samalantan Kabupaten Bengkayang. Jurnal Sains Mahasiswa Pertanian. Vol 2 No 1

Soekartawi. 1993. Prinsip Dasar Ekonomi Pertanian, Teoridan Aplikasi. Edisi Revisi.Jakarta : Rajawali.

Soekartawi. 2002. Prinsip Dasar Ekonomi Pertanian, Teori dan Aplikasinya. Jakarta : PT.Raja Grafindo Persada.

Suprapto E. 2010. Analisis FaktorFaktor yang Mempengaruhi Usahatani Padi Organik di Kabupaten Sragen [Tesis]. Surakarta: Fakultas Ekonomi, Program Pascasarjana Magister Ekonomi dan Studi Pembangunan Universitas Sebelas Maret Surakarta. Tidak dipublikasikan.

Suratiyah, Ken., 2011. Ilmu Usahatani. Jakarta: Penebar Swadaya. 